Brazilian Journal

of Chemical

\title{
FAST-TRACK EVALUATION OF A COMPACT CHEMICALLY ENHANCED-TRICKLING FILTER SYSTEM
}

\author{
S. A. R. Ahmed* \\ Chemical Engineering \& Pilot Plant Department, National Research Center, \\ Phone: +(20) (2) 3371499, Fax: +(20) (2) 3370931, El Tahrir St., Dokki, Cairo, Egypt. \\ E-mail: safaaabdelraouf@yahoo.com
}

(Received: March 20, 2006 ; Accepted: September 27, 2006)

\begin{abstract}
With the more Stringent legislations pertinent to the management of industrial effluents, it deemed necessary to develop an efficient compact, low cost treatment system that complies with applicable laws. Numerous versions of chemically enhanced - biological treatment schemes are commercially established. Chemically enhanced-trickling filter has been perceived as an efficient intervention scheme. This paper presents a fast-track approach for estimation of the minimum total annual treatment cost for the proposed Chemically Enhanced Primary Treatment/ Trickling Filter (CEPT-TF) system under given sets of conditions. The effect of different chemicals has been incorporated through empirical performance formulas. In addition, the influence of the type and characteristic of the media filter has been also addressed. The analysis of the results of the performance of the first stage of the treatment scheme tends to indicate that about $80 \%$ of the biological pollution load can be removed by the upstream chemical treatment at the optimal dose. The optimal economic dose of iron salts ranges from 30 to $40 \mathrm{ppm}$ according to unit capacity and characteristics of the influent. Further, the effect of biological filter media type on the total annual cost has been found to be relatively insignificant (6-16) \%

Keywords: Chemically enhanced; Trickling filter; Industrial wastewater; Simulation; Cost.
\end{abstract}

\section{INTRODUCTION}

Chemically enhanced-biological treatment systems manifest numerous merits including, compact structure that decreases footprint and capital cost and possibilities of tolerating peak flows or peak loads which could be achieved via increasing the applied chemical doses, removal of considerable percentage of the non degradable matter and possibilities of targeting hazardous contaminants at the first upstream chemical treatment.

Earlier reported field and R\&D investigations have indicated the superior performance of chemical treatment for industrial effluents management (Willem 1940 and Gordon 1967). Robinson et al
(2001), observed poor removal of acid dyes but excellent removal of direct dye with ferric chloride dose of about $50 \mathrm{ppm}$. Irene (2000) indicated optimal doses of ferric chloride of $40-50 \mathrm{ppm}$ for a COD reduction of (65-85\%) and TSS reduction of (90-100 $\%)$ for several wastewater plants in Brazil. Other studies have addressed the performance of pilot and full scale trials using dosages of (20-45), (60-100) and (0-2) $\mathrm{ppm}$ for $\mathrm{FeCl3}$, alum and polymer respectively to achieve (70-82)\% and (35-60)\% removal of SS and BOD respectively (Nenov 1995 and Nandy 2002).

On the other hands, trickling filter (TF) is a commercially established cost effective technique for biodegradable loads and ammonia removal from

*To whom correspondence should be addressed 
municipal and industrial effluents. New trickling filter installations are controlled by, and take advantages of, the benefits offered by various media types and shapes in addition to simple operation, low power consumption and low sludge production, (Mann 1997 and Randall 1997). In spit of these advantages, it is relatively liable for clogging and the nitrification capacity loads may be decreased by the sensitivity of autotrophic bacteria to shock loads. Also, for concentrated wastes, a high rate of recirculation would be required for significant reduction of organics.

Biological filter is particularly suited for treatment of moderate BOD load or as a polishing step in combination with other techniques (WEF 1996, Stadterman 1995 and Parker 1996). It could also be used, in some cases, as a roughing filter for a high-strength wastewater (USEPA 2000). TFs, are currently used in conjunction with other treatment methods to treat wastewaters from refineries, pharmaceuticals, pulp and paper, textile mills, tanneries, breweries and distilleries (Oeller 1997, Pedersen 1997 and Rusten 1996), gases decontamination and pretreatment of volatile organic compounds (Miao 2005, Koh 2004, Neal 2000, Lu 2003, Wang 2002) and in potable water treatment for the removal of iron (Michalakos 1997), manganese (Gouzinis 1998) and nitrifying purposes (Vayenas 1995). TFs are conventionally teamed up with activated sludge to reduce the mixed flow to the later (De Clercq 1999).

The first process design approach of TF using fundamental principals was primarily discussed by Velz (1948). Recently, Seguret et al (2000) have studied the hydrodynamic behavior of eight full scale trickling filters (stone and plastic packed) through the investigation of RTD and the free drainage volume. The results indicated that different types of packing do not have the same retention time. Vayenas et al (1997) have developed other dynamic model, which describes nitrification in TF. The results predict that the best moment to start the continues operation is the moment when a maximum in nitrate and a minimum in nitrite concentrations is observed, otherwise a nitrobacter phenomena will occur which leads to filter failure. Pedersen and Arvin (1997) have studied the overall mass transfer coefficient in a trickling filter for treatment of toluene-containing waste gas. The overall mass transfer coefficient value was $25-140 \%$ larger in the trickling filter with a biofilm present than in the clean biotic system. The difference has been explained by improved wetting and, consequently, an enlarged mass transfer area. Kroumins et al (2000) have developed a mathematical model that predicts relationship between Reynolds number and the probability distribution of flow rate under trickling flow.

Study of flow pattern characterization has been conducted by Seguret (2000) and Gouzinis (1998). They concluded that, manganese removal efficiency up to $94 \%$ was achieved for sufficiently high RT in a sequential batch reactor, while it was found to be inadequate for continues operation mode.

Combining chemical precipitation and biological filtration enable efficient integrated compact treatment that is characterized by small process footprint, reliability, flexibility, and of improved economics (Suman 2005, Alaton 2004, Rusten 1996 and Parker 1996). However, due to the availability of different treatment chemicals (coagulants and flocculants) and also the wide spectrum of filter media, the assessment and design procedures are rather complicated and may require limited or detailed experimental work. A fast-track approach (FTA) that reduces size of the choice matrix to a few systems will be highly useful for decision support purposes. The developed FTA is based on the extensive body of reported data on both chemical and biological filtration.

This article is concerned with the development and assessment of the proposed FTA for identification of a low cost CEPT-TF system based on the available technical and economic data on CEPT and TF media characteristics.

\section{APPROACH AND METHODOLOGY}

For the CEPT-TF system addressed in this work, as depicted in Fig. (1), various recommended coagulants are investigated. The coagulants selected; include Ferric Chloride (FC), Alum (A) and Ferrous Sulfate (FS). For trickling filter module several types of media have been selected including, stones, plastic, flocor, surfpac, PVC, slag \& granite and glass.

The adopted approach involves thorough investigation of the relationships governing the design and operation of the proposed integrated system and the related cost indicators. 


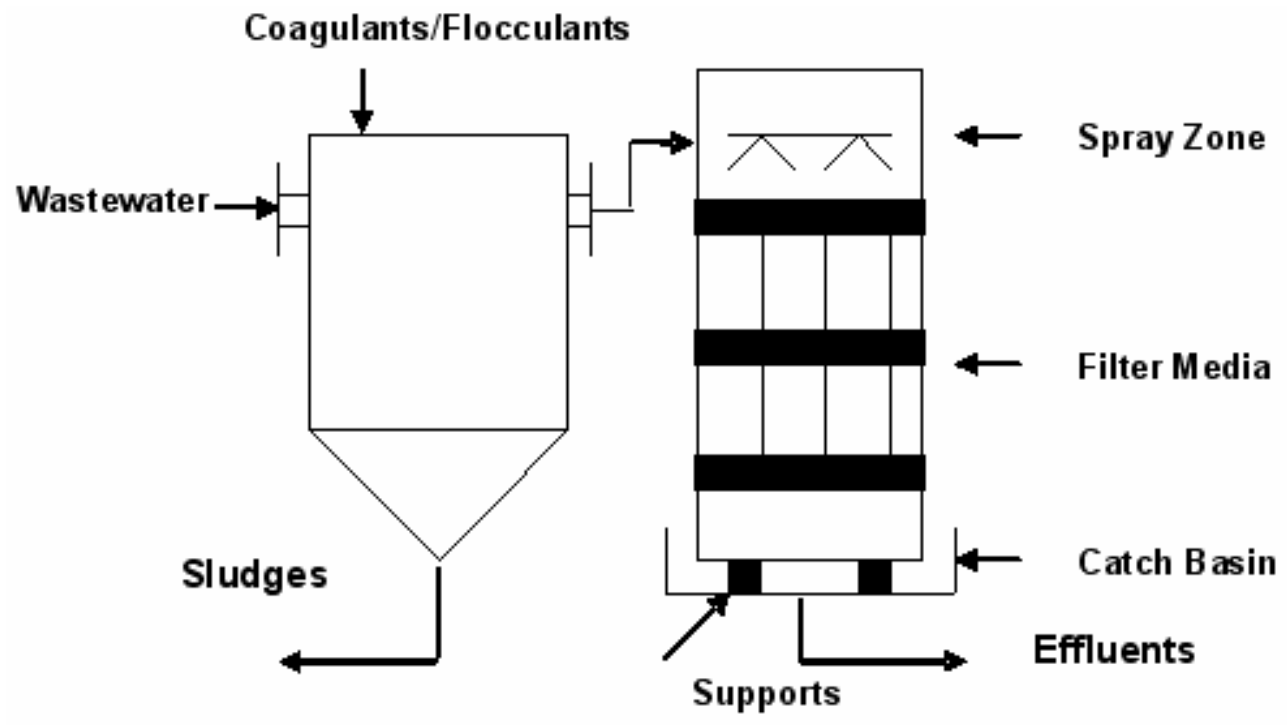

Figure 1: Flow Diagram of the Proposed CEPT-TF System

\section{CEPT/TF Modeling}

\section{a) CEPT Module}

CEPT module performance has been investigated through the correlation of technical and experimental data pertinent to module efficiency. Generalized equation that correlates the \% removal of SS, BOD and COD as a function of different coagulants at different doses have been formulated for: Industrial wastewater flows within the ranges of 10,000 to $50,000 \mathrm{~m} 3$ /day and $\mathrm{BOD}_{\text {in }}$ ranging between 300 to $800 \mathrm{ppm}$ as follows:

$$
\begin{aligned}
& R(i, j)=a(i, j) *(D)^{\wedge} 3-b(i, j)^{*} \\
& (D)^{\wedge} 2+c(i, j) *(D)+e(i, j)
\end{aligned}
$$

where
$\mathrm{R}$ is the \% removal

I is waste characteristics item no. (1-2)

$\mathrm{J}$ is coagulant no. (1-3)

$\mathrm{a}, \mathrm{b}, \mathrm{c}, \mathrm{e}$ are equation constants

D coagulant dose

The value of the previous coefficients illustrated in Equation (1) are highlighted in Table (1) that presents the specification of $(\mathrm{i}, \mathrm{j})$ matrix.

For a specific flow and retention time, the volume of the primary treatment basin is expressed by:

$$
\mathrm{V}_{\mathrm{C}}=\mathrm{Q} / 24 * \mathrm{Tc}
$$

where

$\mathrm{Q}$ is the wastewater flow rate (m3/day).

Tc is the residence time (hr).

$\mathrm{V}_{\mathrm{C}}$ is the required primary settling volume $\left(\mathrm{m}^{3}\right)$.

Table 1: [i,j] Specification Matrix

\begin{tabular}{|l|l|}
\hline Item & Specification \\
\hline $\mathrm{i}$ for $\mathrm{i}=1$ to 2 & SS, BOD \\
$\mathrm{j}$ for $\mathrm{j}=1$ to 3 & FeCl3, Alum, FeSO4 \\
$\mathrm{a}(1,1), \mathrm{a}(1,2), \mathrm{a}(1,3)$ & $2 * 10^{\wedge}-4,7^{*} 10^{\wedge}-5,2^{*} 10^{\wedge}-4$ \\
$\mathrm{a}(2,1), \mathrm{a}(2,2), \mathrm{a}(2,3)$ & $3 * 10^{\wedge}-4,2^{*} 10^{\wedge}-5,2^{*} 10^{\wedge}-4$ \\
$\mathrm{~b}(1,1), \mathrm{b}(1,2), \mathrm{b}(1,3)$ & $-38^{*} 10^{\wedge}-3,-117^{*} 10^{\wedge}-4,-381^{*} 10^{\wedge}-5$ \\
$\mathrm{~b}(2,1), \mathrm{b}(2,2), \mathrm{b}(2,3)$ & $-505^{*} 10^{\wedge}-4,-65^{*} 10^{\wedge}-4,-47^{*} 10^{\wedge}-3$ \\
$\mathrm{c}(1,1), \mathrm{c}(1,2), \mathrm{c}(1,3)$ & $2.11,0.77,1.97$ \\
$\mathrm{c}(2,1), \mathrm{c}(2,2), \mathrm{c}(2,3)$ & $2.95,0.89,2.73$ \\
$\mathrm{e}(1,1), \mathrm{e}(1,2), \mathrm{e}(1,3)$ & $61.4,60.1,60$ \\
$\mathrm{e}(2,1), \mathrm{e}(2,2), \mathrm{e}(2,3)$ & $31.9,31,30$ \\
\hline
\end{tabular}




\section{b) Trickling Filter Module}

Rational algorithm has been proposed to estimate the fraction of BOD removed from wastewater. Then, TF performance is predicted according to various operating conditions. Further, the economic indicators are estimated in terms of BOD load removed.

The basic concept to correlate the BOD removal performance with operating conditions is (Velz (1948):

$\mathrm{dC} / \mathrm{dh}=-\mathrm{KC}$

where

$\mathrm{C}$ is BOD concentration

$\mathrm{K}$ is Reaction rate constant

$\mathrm{h}$ is media depth by integration:

$$
\mathrm{C} / \mathrm{C}_{0}=\exp (-\mathrm{Kh})
$$

where

$\mathrm{C}_{0}$ is BOD concentration in feed

$\mathrm{C}$ is BOD concentration in effluent

As the BOD removal rate is a function of residence time (Howland 1958)

Then

$$
\mathrm{C} / \mathrm{C}_{0}=\exp \left(-\mathrm{K}_{\mathrm{v}} \theta\right)
$$

where

$\Theta$ is wastewater residence time.

The water residence time have been investigated under various filter operating conditions and experimentally correlated as follow:

$\theta=\mathrm{f}\left(\mathrm{q}_{\mathrm{e}}, \mathrm{a}_{\mathrm{e}}, \mathrm{h}\right)$

Then

$$
\theta=\alpha \dot{\alpha} \mathrm{q}_{\mathrm{e}}{ }^{\mathrm{m} 1} \mathrm{a}_{\mathrm{e}}{ }^{\mathrm{m} 2} \mathrm{~h}^{\mathrm{m} 3}
$$

where

$\alpha$ is empirical constant

$\mathrm{q}_{\mathrm{e}}$ is volumetric flow rate per cross sectional area of filter bed $\left(\mathrm{m}^{3} / \mathrm{m}^{2} \mathrm{hr}\right)$

$a_{e}$ is specific surface area of filter bed $\left(\mathrm{m}^{2} / \mathrm{m}^{3}\right)$

$\mathrm{h}$ is filter media height (m)

$\mathrm{m} 1, \mathrm{~m} 2, \mathrm{~m} 3$ are exponents that have been obtained empirically by many investigators according to various filter media (Hosono 1978, Metcalf 1991, Harrison 1987, Krumins 2000, Seguret 2000).

By substituting of equation (6) into (5)

Then

$$
\mathrm{C} / \mathrm{C}_{0}=\exp \left(-\mathrm{K}_{\mathrm{v}} \quad \dot{\alpha} \quad \mathrm{q}_{\mathrm{e}}{ }^{\mathrm{m} 1} \mathrm{a}_{\mathrm{e}}{ }^{\mathrm{m} 2} \mathrm{~h}^{\mathrm{m} 3}\right)
$$

This equation is valid for the following assumptions:

- Steady state BOD removal with first order kinetics

- Constant microbial concentration

- Constant temperature

- Plug flow wastewater profile

The effective fraction of filter media ó is directly proportional to the operating conditions and consequently the term Kó (effective reaction rate constant) is directly proportional to hydraulic loading in the filter bed for specific media

$\mathrm{K} \dot{\alpha}=f(\mathrm{q}$, specific condition of filter media)

Then

$$
\mathrm{C} / \mathrm{C}_{0}=\exp \left(-\alpha \mathrm{q}_{\mathrm{e}}{ }^{\mathrm{m} 1} \mathrm{a}_{\mathrm{e}}{ }^{\mathrm{m} 2} \mathrm{~h}^{\mathrm{m} 3}\right)
$$

According to the published experimental data concerning the actual operation of trickling filter, the BOD removal efficiency is predicted for different

\begin{tabular}{|c|c|c|c|c|c|}
\hline $\mathbf{S}$ & Type of media & $\begin{array}{c}a_{e} \\
\left(m^{2} m^{-3}\right)\end{array}$ & $\begin{array}{c}q_{\mathrm{e}} \\
\left(\mathrm{m}^{3} \mathrm{~m}^{-2} h r^{-1}\right) \\
\end{array}$ & $\begin{array}{c}\mathbf{h} \\
(\mathbf{m})\end{array}$ & $\begin{array}{c}\text { BOD removal } \\
\text { efficiency equation }\end{array}$ \\
\hline 1 & Whinstone & $30-80$ & $0.016-0.43$ & $0.3-1.83$ & $\exp \left(-0.004 q_{e}^{-0.42} a_{e} h\right)$ \\
\hline 2 & Plastic & 88 & $0.1-1.9$ & $0.31-2$ & $\exp \left(-\left(0.0025 \ln \left(\mathrm{q}_{\mathrm{e}}\right)+0.0048\right) \mathrm{a}_{\mathrm{e}} \mathrm{h} / \mathrm{q}\right)$ \\
\hline 3 & Asbestos & $82-121$ & $1.83-5$ & $1.22-1.56$ & $\exp \left(-0.0028 \mathrm{q}_{\mathrm{e}}^{-0.49} \mathrm{a}_{\mathrm{e}} \mathrm{h} / \mathrm{q}\right)$ \\
\hline 4 & Stone & $30-085$ & $0.43-6.5$ & $3-6$ & $\exp \left(2.69 \mathrm{q}^{-0.45} \mathrm{a}_{\mathrm{e}}^{-0.7} \mathrm{~h} / \mathrm{q}\right)$ \\
\hline 5 & Flocor,Surfpac & $85-180$ & $2.3-5$ & $2-3.5$ & $\exp \left(-3.445 \mathrm{q}_{\mathrm{e}}^{0.5241} \mathrm{a}_{\mathrm{e}}^{-0.78} \mathrm{~h} / \mathrm{q}\right)$ \\
\hline 6 & PVC & $89-164$ & $0.17-0.4$ & $0.3-1.25$ & $\exp \left(-\left(4.9 \mathrm{q}_{\mathrm{e}}+1.57\right) \mathrm{a}_{\mathrm{e}}^{-0.86} \mathrm{~h} / \mathrm{q}\right)$ \\
\hline 7 & Slag, Granite & $80-165$ & $0.34-0.76$ & up to 1.8 & $\exp \left(-\left(9.7 .9 \mathrm{q}_{\mathrm{e}}+1.3\right) \mathrm{a}_{\mathrm{e}}^{-1.1} \mathrm{~h} / \mathrm{q}\right)$ \\
\hline 8 & Fiber Glass Sheet & $36-164$ & $0.17-2.38$ & $1.22-5.5$ & $\exp \left(-\left(10.1 \mathrm{q}_{\mathrm{e}}^{0.45} \mathrm{a}_{\mathrm{e}}^{-1.05} \mathrm{~h} / \mathrm{q}\right)\right.$ \\
\hline
\end{tabular}
trickling filter media as depicted in Table (2)

where

$\alpha$ is empirical constant.

Table 2: Trickling Filter Technical Sheet ${ }^{[a]}$

${ }^{\text {[a] } H o s o n o ~ 1978, ~ M e t c a l f ~ 1991, ~ H a r r i s o n ~ 1987, ~ W h e a t l e y ~ 1976, ~ L o g a n ~ 2000, ~ P u l l e n ~ 1976, ~ G r a y ~ 1983, ~ H e m m i n g ~ 1978, ~ P u l l e n ~}$

1976,Christoulas 1990, Krumins 2000, Seguret 2000

$a_{e}$ - is specific surface area of filter bed $\left(\mathrm{m}^{2} / \mathrm{m}^{3}\right)$

$\mathrm{q}_{\mathrm{e}}$ - is volumetric flow rate per cross sectional area of filter bed $\left(\mathrm{m}^{3} / \mathrm{m}^{2} \mathrm{hr}\right)$

$\mathrm{h}$ - is filter media height $(\mathrm{m})$ 


\section{Simulation}

Simulation of CEPT/TF system has been developed according to the proposed technical models. The simulation approach has been conducted for various controlling indicators include: coagulant type\& dose,
TF media type \& characteristics, treatment capacity and organic load. According to the developed simulation model involving the technical aspects, a financial profile is estimated including capital cost, operating cost and the total annual cost. Block flow diagram of the developed approach has been depicted in Fig. (2).

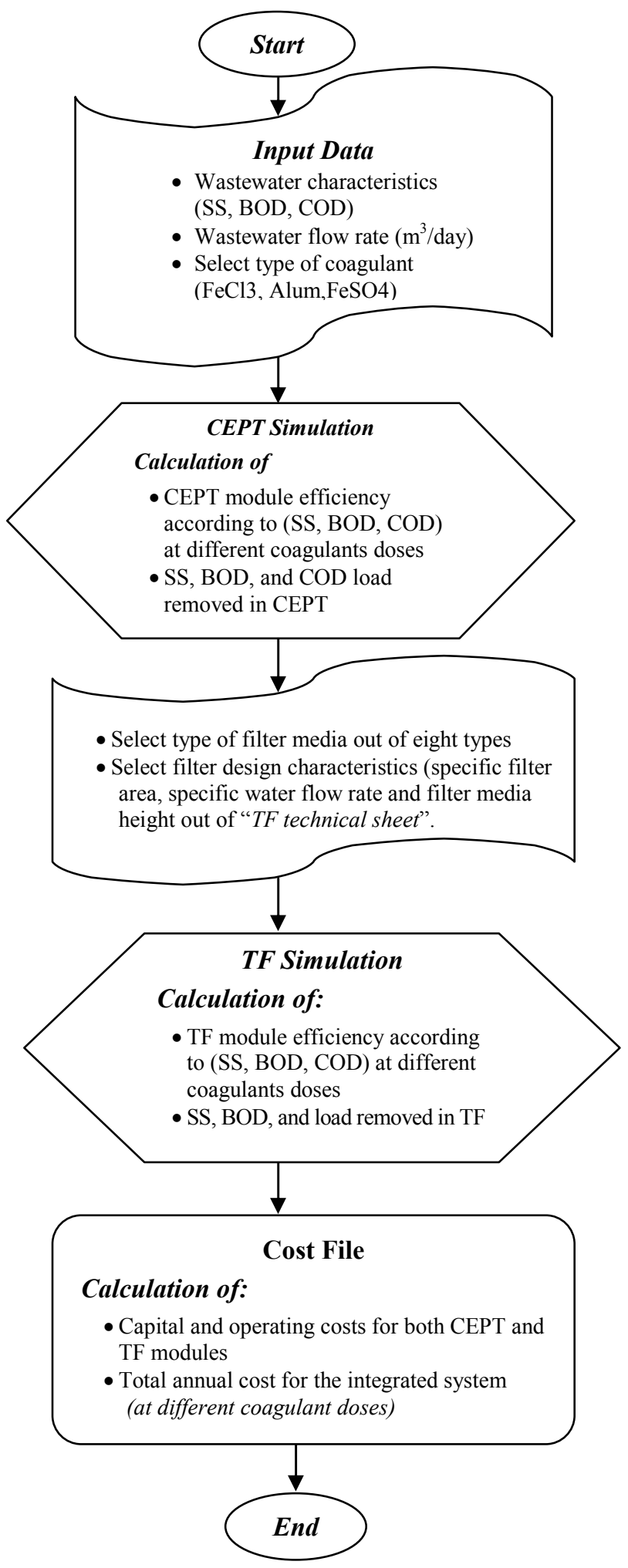

Figure 2: Block flow Diagram of the Developed Approach 


\section{Investment and Operating Cost Estimation}

Capital and operating cost estimates have been investigated according to cost functions that predict cost indicators as correlated with the controlling technical parameters of each module. Also, the materials and chemicals cost are estimated according to the international prevailing prices. Adapted cost functions and data are presented in Table (3).

Table 3: Cost Functions of the Proposed System

\begin{tabular}{|l|l|l|}
\hline \multicolumn{1}{|c|}{ Serial } & Module & Cost Function \$ \\
\hline I & Capital Cost & \\
\hline I.1 & CEPT & $3150 \times$ A $^{0.68}$ \\
I.1.1 & Primary Settler (CW) & $7600 \times$ A $^{0.3}$ \\
I.2 & Settler Rack (EM) & $7.2 \mathrm{E}-04^{*}(\text { BOD load removed })^{\wedge} 0.94$ \\
\hline II & Trickling filter & \\
\hline II.1 & Operating Cost & $0.12(\$)$ \\
II.1.1 & CEPT & $380(\$ /$ ton $)$ \\
II.1.2 & kWh & $185(\$ /$ ton $)$ \\
II.1.3 & FeCl $(100 \%$ conc. $)$ & $100(\$ /$ ton $)$ \\
II.1.4 & FeSO4 & $8 \mathrm{E}-06 *(\mathrm{BOD}$ load removed $)+0.15$ \\
\hline II.2 & Alum & \\
\hline
\end{tabular}

Where: A - is the area of module $\left(\mathrm{m}^{2}\right) ; \mathrm{V}$ - is the volume of module $\left(\mathrm{m}^{3}\right) ; \mathrm{CW}$ - is civil work; EM - is electromechanical parts; BOD - load: kg/day

\section{RESULTS AND DISCUSSIONS}

Simulation results for the adopted CEPT-TF approach are presented, analyzed and discussed as applied to typical textile wastewater characteristics.

\section{Simulation and Cost Estimation}

Technical and economic analysis has been conducted to identify the profiles for various design and operating parameters as outlined below.

\section{a) Simulation for TF-Media:}

For selected coagulant, capacity and waste characteristics: total annual cost has been estimated for different filter media at different $\mathrm{FeCl} 3$ doses as depicted in Fig. (3). The highest TAC is detected at zero coagulant and decrease till reaching min. The optimum coagulant dose is recorded at about $40 \mathrm{ppm}$ $\mathrm{FeCl} 3$ for all type of $\mathrm{TF}$ media. Whinstone (filter media 1) has addressed the min TAC at different doses. Wide difference, about 150,000 US\$, is estimated between the module with the highest TAC (CEPT-TF Slag media) and the lowest TAC (CEPT-TF whinstone media), at no or relatively low coagulant dose, while reaching about 33,000 US\$ at the optimum dose. Further, slight differences may be traced at coagulant doses exceeding the optimum dose.

\section{b) Coagulant Type}

The results of changing coagulants types on the total annual cost of the integrated system at different TF-media have been investigated. It is noticed that the order of TAC-curves is independent of coagulant type (The same order for different coagulants) as depicted in Fig. (4). For integrated system with whinstone media the optimal coagulant dose is 35 ppm for both ferric and ferrous salts with corresponding min TAC: 493,000 and 463,000 US\$ respectively. In the case of alum, the pattern of the TAC-dose curve is linear and no min cost could be detected within the investigated dosage range. 


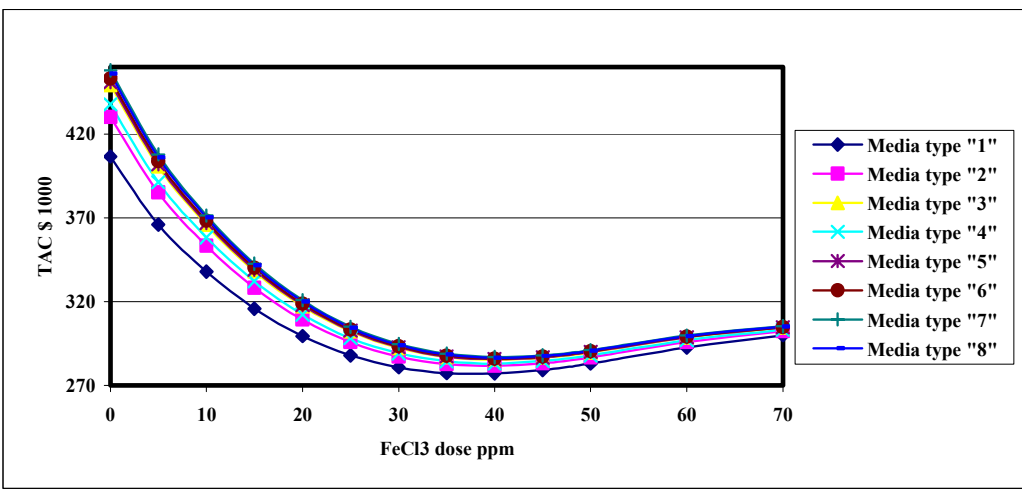

\begin{tabular}{|lc|}
\hline Wastewater Flow Rate M3/day & 10000 \\
SS inlet, ppm & 700 \\
BOD inlet, ppm & 500 \\
Type of Chemical used in CEPT & Ferric Chloride \\
Type of Media used in Trickling Filter & $" 1-8 "$ \\
\hline
\end{tabular}

Figure 3: Change of Total Annual Cost of CEPT-TF System with Varying $\mathrm{FeCl} 3$ Dose at Various TF Media for $10000 \mathrm{~m} 3 /$ day
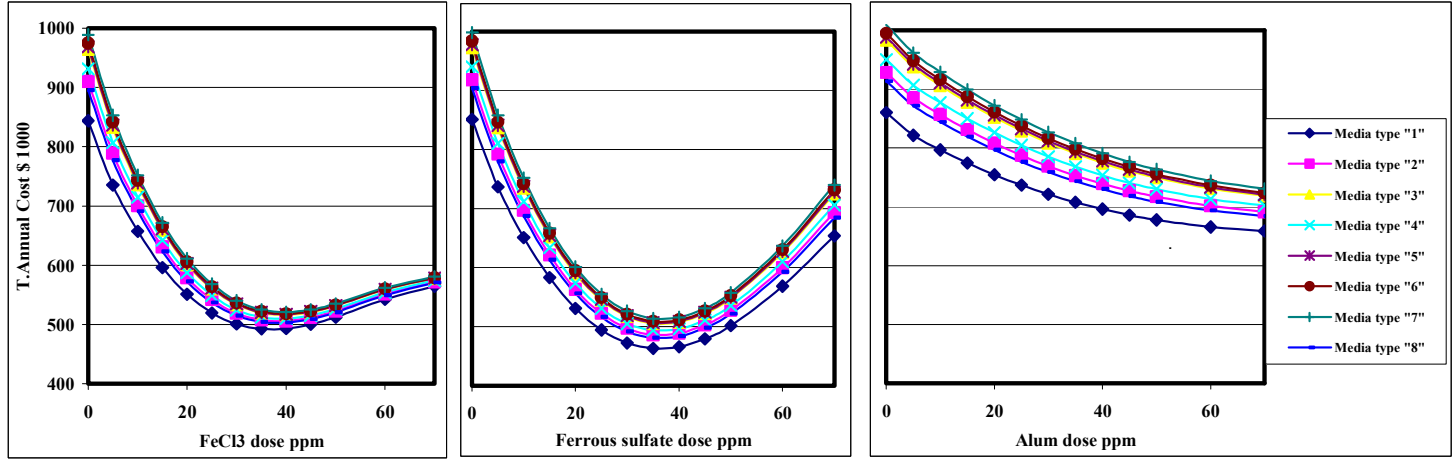

\begin{tabular}{|ll|}
\hline Unit Capacity m3/day & 30000 \\
SS inlet, ppm & 700 \\
BOD inlet, ppm & 500 \\
Type of Coagulant used in CEPT & FeCl3,Ferrous sulfate,Alum \\
Type of Media used in Trickling Filter & $" 1-8 "$ \\
\hline
\end{tabular}

Figure 4: Change of Total Annual Cost of CEPT-TF System with Varying Coagulant Dose at Various TF Media for 30000 m3/day

Fig. (5) represents the lowest and the highest TAC curves, according to different coagulants, estimated for whinstone and granite filter media respectively. It indicates that for granite or slag media, the optimum coagulant doses are $40 \mathrm{ppm}$ and $35 \mathrm{ppm}$ with TAC of about $(520,000$ and 513,000$)$ US\$ for ferric chloride and ferrous sulfate coagulants respectively. Although, ferrous sulfate indicates lower TAC for all media types, $\mathrm{FeCl} 3$ has superior performance than others. At the optimum dose, the effluent BOD was 40, 50 and $95 \mathrm{ppm}$ for $\mathrm{FeCl} 3$, FeSO4 and alum respectively. Moreover, ferrous sulfate produces greater amount of sludge that will affect the sludge treatment cost which has not been accounted for within the scope of this work.

\section{c) Capacity Change}

Fig. (6) represents the TAC for selected coagulant at different dose for unit capacity 30,000 and 50,000 $\mathrm{m} 3$ /day respectively. It is concluded that increasing the unit capacity affects the optimum coagulants doses and changes the relative order of media-TAC curves irrespective of coagulant type. The results indicate that: while, CEPT-TF system with slag or granite media shows the highest TAC curve for unit capacity below $40,000 \mathrm{~m} 3 /$ day, it has the lowest TAC curve for unit capacity $50,000 \mathrm{~m} 3 /$ day. 

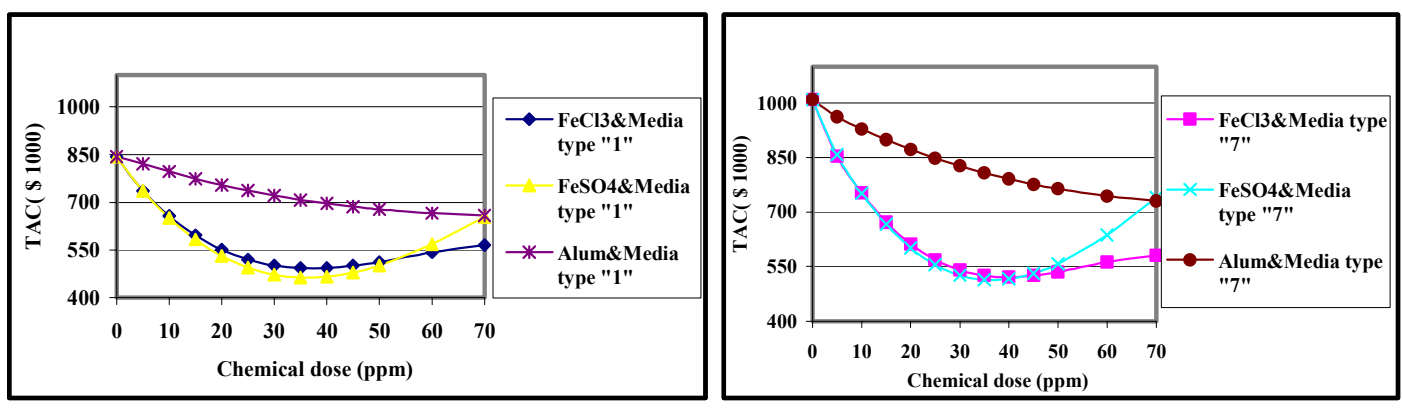

\begin{tabular}{|ll|}
\hline Unit Capacity & 30000 \\
SS inlet, ppm & 700 \\
BOD inlet, ppm & 500 \\
Type of Coagulant used in CEPT & FeCl3,Ferrous sulfate,Alum \\
Type of Media used in Trickling Filter & $" 1,7 "$ \\
\hline
\end{tabular}

Figure 5: Change of Total Annual Cost of CEPT-TF System with Different Varying Coagulant Type and Dose for Selected TF Media
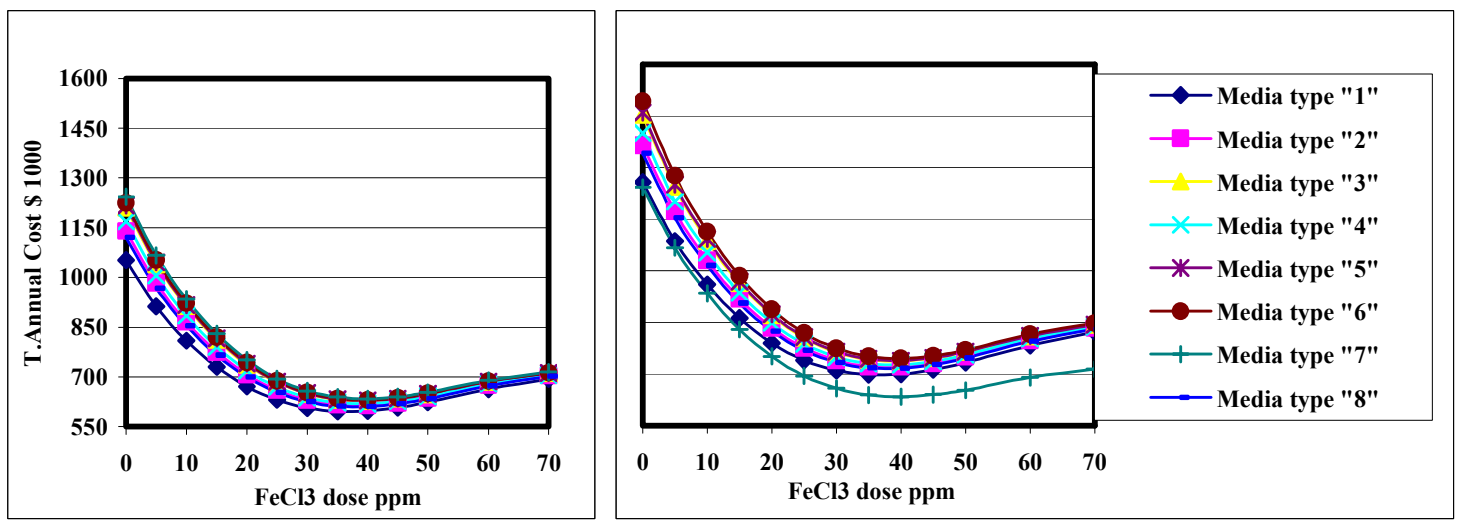

\begin{tabular}{|ll|}
\hline Unit Capacity & 30000 and 50000 \\
SS inlet, ppm & 700 \\
BOD inlet, ppm & 500 \\
Type of Coagulant used in CEPT & Ferric Chloride \\
Type of Media used in Trickling Filter & $" 1-8 "$ \\
\hline
\end{tabular}

Figure 6: Change of Total Annual Cost of CEPT-TF System with Varying FeCl3 dose at Various Capacity

\section{d) Waste Characteristics:}

TAC is relatively sensitive to change in waste load at small coagulant and tends to decrease for higher coagulant dose. It is observed that the optimum dose has been moved from 30 to $47 \mathrm{ppm}$ $\mathrm{FeCl3}$ when BOD influent increases from 300 to $800 \mathrm{ppm}$ respectively as presented in Fig. (7). The TAC increases by 600,000 US $\$$ and 120,000 US\$ at zero and optimal coagulant dose respectively. The total operating cost and the $\mathrm{TF}$ annualized cost have increased by about 65,000 US\$.
Table (4) presents the optimum value of ferric chloride dose and the corresponding TAC at different BOD feed load.

\section{e) Filter Characteristics:}

The influence of varying filter characteristics that include: specific filter surface area, specific flow rate and filter height, of selected filter media "PVC", on TAC are presented in Fig. (8). It has been noted that: the TAC curves are slightly sensitive to the change in filer characteristics especially at and above the optimum dose. 


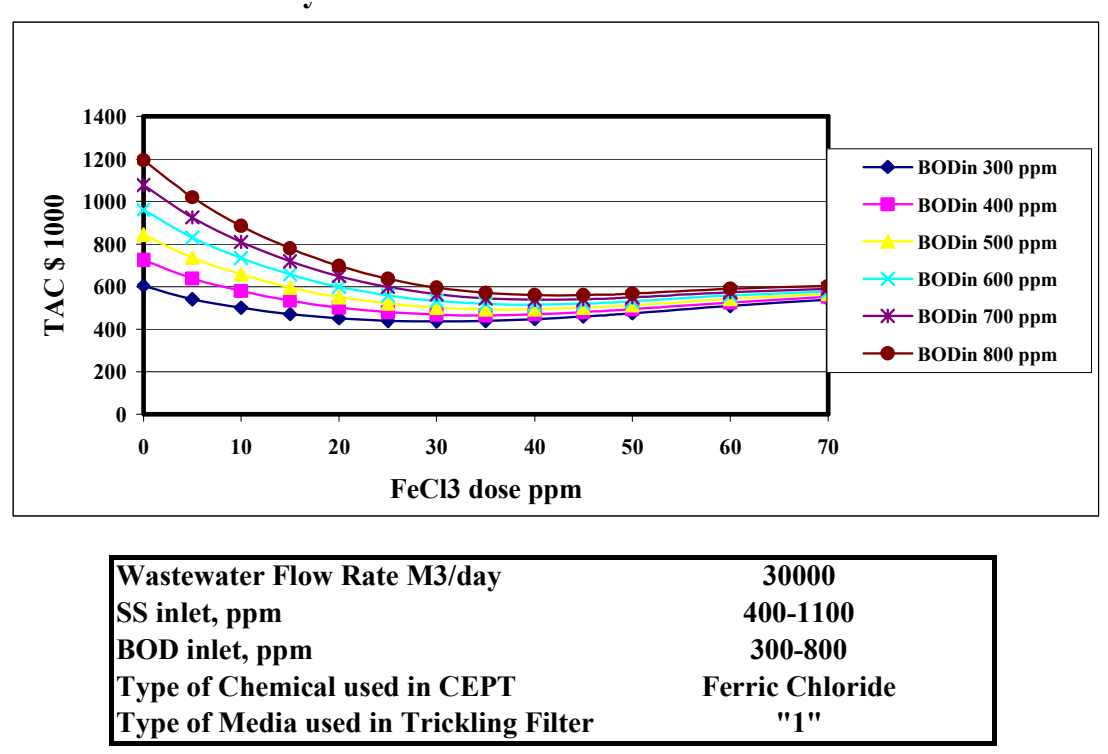

Figure 7: Change of TAC with Different FeCl3 Dose for CEPT-TF System for Different Waste Characteristics

Table 4: Optimum Ferric Chloride Dose and the Corresponding TAC at Different BOD Load

\begin{tabular}{|c|c|c|}
\hline $\begin{array}{c}\text { BOD Load } \\
\text { ppm }\end{array}$ & Optimum FeCl3 Dose & TAC \\
US \$ 1000 \\
\hline 300 & ppm & 436 \\
400 & 30 & 466 \\
500 & 35 & 493 \\
600 & 37 & 516 \\
700 & 40 & 538 \\
800 & 42 & 556 \\
\hline
\end{tabular}

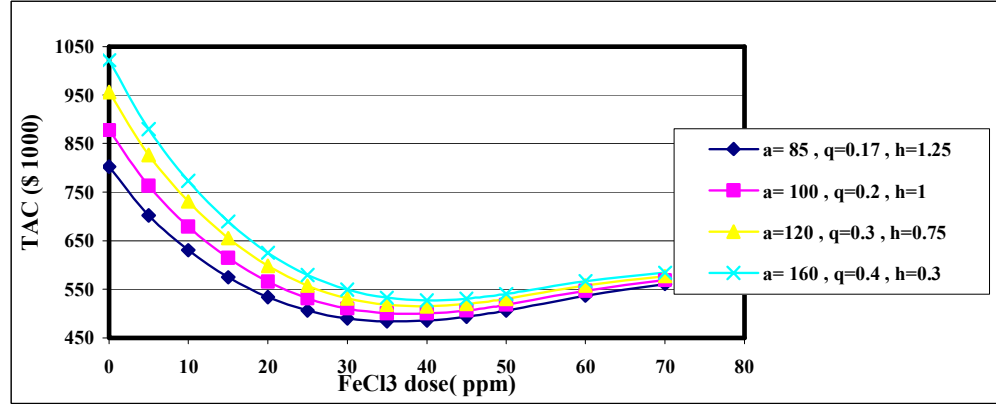

\begin{tabular}{|lc|}
\hline Wastewater Flow Rate M3/day & 30000 \\
SS inlet, ppm & 700 \\
BOD inlet, ppm & 500 \\
Type of Chemical used in CEPT & Ferric Chloride \\
Type of Media used in Trickling Filter & "6" \\
\hline
\end{tabular}

Figure 8: Change of TAC with $\mathrm{FeCl} 3$ Dose at Different TF Characteristics for Selected Media 


\section{Sensitivity Analysis}

\section{a) Capacity Definition}

The amount of BOD removed per $\mathrm{kg}$ coagulant at and around the optimum coagulant dose for different CEPT-TF modules using different coagulant types have been investigated as depicted in Table (5). The most efficient coagulant has been found to be $\mathrm{FeCl} 3$ that shows greater amount of BOD removal ranging between 14-16.5 kg BOD $/ \mathrm{kg}$ coagulant added for different CEPT-TF modules at the optimum $\mathrm{FeCl} 3$ doses.

\section{b) Cost Definition}

Table (6) presents the coagulant cost in $\$ / \mathrm{kg}$ BOD removed at and around the optimum dose for different CEPT-TF modules using different coagulant types. According to coagulant cost, $\mathrm{FeSO} 4$ has the lowest annual cost per kg BOD removed that ranges between 0.008-.006 $\$ / \mathrm{kg}$ BOD at optimum coagulant dose for different integrated CEPT-TF modules.

\section{c) Coagulants Performance Profile}

Coagulant performance has been presented as \% BOD removed distribution with coagulant $\%$ of the maximum dose as shown in Fig. (9). About $87 \%$ of the BOD load have been removed using about $12.5 \%$ of the coagulant $\%$ of max dose and more than $95 \%$ removal of BOD have been achieved using $50 \%$ of coagulant max dose.

Table 5: Capacity Definition

\begin{tabular}{|c|c|c|c|c|c|}
\hline Coagulant dose (ppm) & 25 & 30 & 35 & 40 & 45 \\
\hline & \multicolumn{5}{|c|}{ Kg BOD removed /Kg coagulant } \\
\hline \multicolumn{6}{|l|}{$\mathrm{I}^{-\mathrm{FeCl}_{3}}$} \\
\hline CEPT & 15.7 & 13.8 & 12.3 & 11.0 & 10.0 \\
\hline CEPT-TF Media "1" & 18.9 & 15.9 & 13.8 & 12.1 & 10.8 \\
\hline CEPT-TF Media "2" & 19.3 & 16.2 & 13.9 & 12.2 & 10.9 \\
\hline CEPT-TF Media "3" & 19.5 & 16.4 & 14.1 & 12.3 & 11.0 \\
\hline CEPT-TF Media "4" & 19.4 & 16.2 & 14.0 & 12.3 & 11.0 \\
\hline CEPT-TF Media "5" & 19.6 & 16.2 & 14.1 & 12.4 & 11.0 \\
\hline CEPT-TF Media "6" & 19.6 & 16.4 & 14.1 & 12.4 & 11.0 \\
\hline CEPT-TF Media "7" & 19.7 & 16.5 & 14.1 & 12.4 & 11.0 \\
\hline CEPT-TF Media "8" & 19.6 & 16.4 & 14.1 & 12.4 & 11.0 \\
\hline \multicolumn{6}{|l|}{$\mathrm{II}^{-\mathrm{FeSO}_{4}}$} \\
\hline CEPT & 14.6 & 12.7 & 11.1 & 9.7 & 8.6 \\
\hline CEPT-TF Media "1" & 18.6 & 15.6 & 13.5 & 11.8 & 10.5 \\
\hline CEPT-TF Media "2" & 18.1 & 15.0 & 12.7 & 11.0 & 9.5 \\
\hline CEPT-TF Media "3" & 19.4 & 16.2 & 13.9 & 12.2 & 10.8 \\
\hline CEPT-TF Media "4" & 19.2 & 16.1 & 13.8 & 12.1 & 10.7 \\
\hline CEPT-TF Media "5" & 19.5 & 16.3 & 14.0 & 12.2 & 10.9 \\
\hline CEPT-TF Media "6" & 19.5 & 16.3 & 14.0 & 12.2 & 10.9 \\
\hline CEPT-TF Media "7" & 19.6 & 16.4 & 14.0 & 12.3 & 10.9 \\
\hline CEPT-TF Media "8" & 19.0 & 15.9 & 13.7 & 12.0 & 10.6 \\
\hline \multicolumn{6}{|l|}{ III-Alum } \\
\hline CEPT & 9.7 & 8.6 & 7.7 & 7.1 & 6.5 \\
\hline CEPT-TF Media "1" & 17.3 & 14.6 & 12.6 & 11.1 & 9.9 \\
\hline CEPT-TF Media "2" & 18.2 & 15.3 & 13.1 & 11.6 & 10.3 \\
\hline CEPT-TF Media "3" & 18.9 & 15.8 & 13.6 & 11.9 & 10.6 \\
\hline CEPT-TF Media "4" & 18.5 & 15.5 & 13.3 & 11.7 & 10.4 \\
\hline CEPT-TF Media "5" & 19.0 & 15.9 & 13.6 & 12.0 & 10.7 \\
\hline CEPT-TF Media "6" & 19.1 & 15.9 & 13.7 & 12.0 & 10.7 \\
\hline CEPT-TF Media "7" & 19.2 & 16.1 & 13.8 & 12.1 & 10.8 \\
\hline CEPT-TF Media "8" & 18.0 & 15.1 & 13.0 & 11.5 & 10.2 \\
\hline
\end{tabular}


Table 6: Cost Definition

\begin{tabular}{|c|c|c|c|c|c|}
\hline Coagulant dose(ppm) & 25 & 30 & 35 & 40 & 45 \\
\hline & \multicolumn{5}{|c|}{ Coagulant cost \$/BOD removed } \\
\hline $\mathrm{I}-\mathrm{FeCl}_{3}$ & & & & & \\
\hline CEPT & 0.024 & 0.027 & 0.031 & 0.034 & 0.038 \\
\hline CEPT-TF Media "1" & 0.020 & 0.024 & 0.028 & 0.031 & 0.035 \\
\hline CEPT-TF Media "2" & 0.020 & 0.024 & 0.027 & 0.031 & 0.035 \\
\hline CEPT-TF Media "3" & 0.019 & 0.023 & 0.027 & 0.031 & 0.035 \\
\hline CEPT-TF Media "4" & 0.020 & 0.023 & 0.027 & 0.031 & 0.035 \\
\hline CEPT-TF Media "5" & 0.019 & 0.023 & 0.027 & 0.031 & 0.035 \\
\hline CEPT-TF Media "6" & 0.019 & 0.023 & 0.027 & 0.031 & 0.035 \\
\hline CEPT-TF Media "7" & 0.019 & 0.023 & 0.027 & 0.031 & 0.034 \\
\hline CEPT-TF Media "8" & 0.019 & 0.023 & 0.027 & 0.031 & 0.034 \\
\hline \multicolumn{6}{|l|}{$\mathrm{II}_{-\mathrm{FeSO}}$} \\
\hline CEPT & 0.007 & 0.008 & 0.009 & 0.010 & 0.012 \\
\hline CEPT-TF Media "1" & 0.005 & 0.006 & 0.007 & 0.008 & 0.010 \\
\hline CEPT-TF Media "2" & 0.006 & 0.007 & 0.008 & 0.009 & 0.010 \\
\hline CEPT-TF Media "3" & 0.005 & 0.006 & 0.007 & 0.008 & 0.009 \\
\hline CEPT-TF Media "4" & 0.005 & 0.006 & 0.007 & 0.008 & 0.009 \\
\hline CEPT-TF Media "5" & 0.005 & 0.006 & 0.007 & 0.008 & 0.009 \\
\hline CEPT-TF Media "6" & 0.005 & 0.006 & 0.007 & 0.008 & 0.009 \\
\hline CEPT-TF Media "7" & 0.005 & 0.006 & 0.007 & 0.008 & 0.009 \\
\hline CEPT-TF Media "8" & 0.005 & 0.006 & 0.007 & 0.008 & 0.009 \\
\hline \multicolumn{6}{|l|}{ III-Alum } \\
\hline CEPT & 0.019 & 0.022 & 0.024 & 0.026 & 0.028 \\
\hline CEPT-TF Media "1" & 0.011 & 0.013 & 0.015 & 0.017 & 0.019 \\
\hline CEPT-TF Media "2" & 0.010 & 0.012 & 0.014 & 0.016 & 0.018 \\
\hline CEPT-TF Media "3" & 0.010 & 0.012 & 0.014 & 0.016 & 0.017 \\
\hline CEPT-TF Media "4" & 0.010 & 0.012 & 0.014 & 0.016 & 0.018 \\
\hline CEPT-TF Media "5" & 0.010 & 0.012 & 0.014 & 0.015 & 0.017 \\
\hline CEPT-TF Media "6" & 0.010 & 0.012 & 0.014 & 0.015 & 0.017 \\
\hline CEPT-TF Media "7" & 0.010 & 0.012 & 0.013 & 0.015 & 0.017 \\
\hline CEPT-TF Media "8" & 0.010 & 0.012 & 0.014 & 0.016 & 0.018 \\
\hline
\end{tabular}

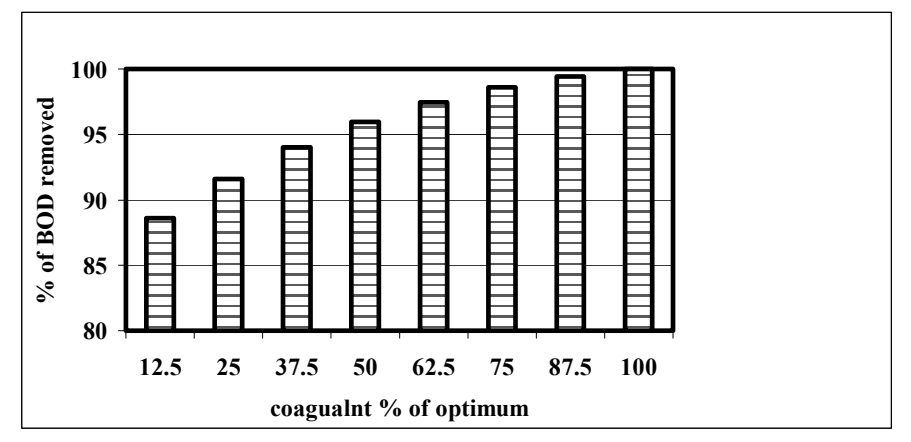

\begin{tabular}{|lc|}
\hline Wastewater Flow Rate M3/day & 30000 \\
SS inlet, ppm & 700 \\
BOD inlet, ppm & 500 \\
Type of Chemical used in CEPT & Ferric Chloride \\
Type of Media used in Trickling Filter & "1" \\
\hline
\end{tabular}

Figure 9: Coagulants Performance Profile 


\section{CONCLUSIONS}

Technical and economic assessment of CEPT-TF system in industrial wastewater treatment has been evaluated. A simulation approach has been developed for the proposed system through theoretical considerations \& empirical assumption based on experimental data obtained from pilot and full scale published data. A complete financial profile has been adopted involving capital, operating and total cost for the selected modules and integrated system. An integrated fast track approach for prioritirising the total annual treatment cost for different CEPT-TF options under a giving set of technical constrains has been developed.

The results indicate that, major part of BOD load is removed within the CEPT module. More than 85 $\%$ of BOD removed by the overall system is carried out in CEPT module with coagulant dose up to 12.5 $\%$ of the optimum dose (40 ppm). Moreover The percentage of CEPT module of TAC represents about $38,28,19 \%$ on using: ferric chloride, ferrous sulfate and alum respectively at $40 \mathrm{ppm}$ dose, 10,000 $\mathrm{m} 3 /$ day capacity and $500 \mathrm{ppm}$ BOD load.

The optimum coagulant dose ranges between 30 $45 \mathrm{ppm}$ (for iron salt) depending on coagulant type, waste load and unit capacity (according to the investigated constrains). The correlation between alum dose and TAC has been proposed to be linear. Minimum TAC has been changed according to the giving technical considerations. In most cases, CEPT-whinstone trickling filter system has proved to be the lowest TAC system, with min technical performance, while CEPT-PVC trickling filter system has proved to be the greatest TAC with optimum performance.

It is noticed that, the TAC for the proposed integrated system is relatively sensitive to change in waste load at zero coagulants and the sensitivity is relatively less for higher coagulants dose. Increase in unit capacity affect the optimum coagulant dose location and change the relative order of TACcurves of the proposed integrated CEPT-TF system irrespective of coagulant type.

\section{NOMENCLATURE}
A Alum
$\mathrm{a}, \mathrm{b}, \mathrm{c}, \mathrm{d}$ equations constants according to various filter media
$a_{e} \quad$ Specific surface area of filter bed $\left(\mathrm{m}^{2} / \mathrm{m}^{3}\right)$

\begin{tabular}{|c|c|}
\hline BOD & Biological Oxygen Demand \\
\hline $\mathrm{C}$ & Conc. of the removable BOD in effluent \\
\hline $\mathrm{C}_{0}$ & Conc. of the removable BOD in feed \\
\hline CEPT & Chemically Enhanced Primary \\
\hline COD & Chemical Oxygen Demand \\
\hline $\mathrm{D}$ & coagulant dose \\
\hline $\mathrm{FC}$ & Ferric Chloride \\
\hline FM & Filter Media \\
\hline $\mathrm{FM}(\mathrm{n})$ & Filter Media of $n$ where $n=1$ to 8 \\
\hline FS & Ferrous Sulfate \\
\hline $\mathrm{H}$ & filter media height $(\mathrm{m})$ \\
\hline I & waste characteristics item no. (1-2) \\
\hline $\mathrm{J}$ & Coagulant no. (1-3) \\
\hline $\mathrm{K}, \mathrm{K}_{\mathrm{v}}$ & Reaction rate constant $\left(\right.$ time $\left.^{-1}\right)$ \\
\hline PVC & Poly Vinyl Chloride \\
\hline Q & Wastewater flow rate (m3/day) \\
\hline $\mathrm{q}_{\mathrm{e}}$ & $\begin{array}{l}\text { Volumetric flow rate per cross sectional } \\
\text { area of filter bed }\left(\mathrm{m}^{3} / \mathrm{m}^{2} \mathrm{hr}\right)\end{array}$ \\
\hline $\mathrm{R}$ & Percentage Removal \\
\hline SS & Suspended Solid \\
\hline TAC & Total Annual Cost \\
\hline Tc & Residence time (hr) \\
\hline $\mathrm{TF}$ & Trickling Filter \\
\hline TSS & Total Suspended Solid \\
\hline $\mathrm{V}_{\mathrm{C}}$ & Required primary settling volume $\left(\mathrm{m}^{3}\right)$ \\
\hline$\alpha, \alpha$ & Empirical constants \\
\hline
\end{tabular}

\section{REFERENCES}

Metcalf and Eddy, Inc., Wastewater Engineering, Treatment, Disposal and Reuse, McGraw Hill Companies. New York (1991).

Water Environment Federation (WEF), Operation of Municipal Wastewater Treatment Plants, Manual of Practice No. 11, 5th ed. Vol. 2, WEF. Alexandria, Virginia (1996).

Velz, C.J., A Basic Law for the Performance of Biological Filter, Sewage Works Journal, Vol.20, pp 607-617(1948).

Robinson, T. et al, Remediation of Dyes in Textile Effluent: a Critical Review on Current Treatment Technologies with a Proposed Alternative, Bioresearch Technology, Vol. 77, pp 247-255 (2001).

Seguret, F. et al, Hydrodynamic Behavior of Full Scale Trickling Filters, Wat Res. Vol. 34, No 5, pp1551-1558 (2000).

Pedersen, A.R. and Arvin, E., Effect of Biofilm Growth on the Gas-Liquid Mass Transfer in a Trickling Filter for Waste Gas Treatment, Wat.Res.Vol.231, No 8, pp1963-1968 (1997). 
Michalakos, G. D. et al, Removal of Iron from Potable Water Using a Trickling Filter, Wat.Res.Vol.31, No 5, pp 991-996 (1997).

Vayenas, D. V. and Lyberatos, G., On the Design of Nitrifying Trickling Filters for Potable Water Treatment, Wat.Res.Vol.29, No 5, pp1079-1084 (1995).

Guzinis, A.et al, Removal of Mn and Simultaneous Removal of NH3, Fe and Mn from Potable Water Using a Trickling Filter, Wat. Res. Vol. 32, No 8, pp 2442-2450 (1998).

Randall, A.A. et al, Industrial Pretreatment: Trickling Filter Performance and Design, Journal of Environmental Engineering, November, pp 1072-1079 (1997).

Krumins, V. et al, Fluid Velocity Distribution Nitrifying Trickling Filter: Mathematical Model and NMR Calibration, Wat. Res. Vol. 34, No 8, pp 2337-2345 (2000).

Willem, R., Chemical Treatment of Sewage, First Annual Convention of the Sewage Works Federation, Chicago, pp1051-1061 (1940).

Gordon, L., Chemical Treatment of Raw Sewage, Water and Wastes Engineering, July, No7, pp.6163 (1967).

Irene, W. Y., Bench-Scale Study of Chemically Enhanced Primary Treatment in Brazil, Master Thesis for Engineering in Civil and Environmental Engineering, Faculty of Engineering, Brazil (2000).

United States Environmental Protection Agency, Office of Water Washington, D.C., Wastewater Technology Fact Sheet Trickling Filter Nitrification, EPA 832- F-00-015 (2000).

Mann, A.T. and Stephenson, T., Modeling Biological Aerated Filters for Wastewater Treatment, Wat. Res. Vol.31, No 10, pp 2443-2448 (1997).

Harrison, J. R. and Daigger, G. T.," A Comparison of Trickling Filter Media, J. Wat. Pollut. Control Fed. Vol. 59, pp 679-685 (1987).

Stadterman, K. L. et al, Removal and Inactivation of Cryptosporidium oocysts by Activated Sludge Treatment and Anaerobic Digestion,Water Science and Technology Vol.31, Issues 5-6, pp 97-104 (1995).

Parker, D. et al, Design and Operations Experience with Flocculator-Clarifiers in Large Plants, Water Science and Technology, Vol. 33, Issue12, pp163-170 (1996).

Oeller, H.J. et al, Reduction in Residual COD in Biologically Treated Paper Mill Effluents by Means of Combined Ozone and Ozone/UV Reactor Stages, Water Science and Technology Vol. 35, Issues 2-3, pp 269-276 (1997).
Pedersen, A. R. and Arvin, E., Toluene Removal in a Biofilm Reactor for Waste Gas Treatment, Water Science and Technology, Vol. 36, Issuel pp.6976 (1997).

Rusten, B., Siljudalen J. G. and Strand H., Upgrading of a Biological-Chemical Treatment Plant for Cheese Factory Wastewater, Water Science and Technology, Vol. 34, Issue 11, pp 41-49 (1996).

De Clercq, B., Coen, F., Vanderhaegen B. and Vanrolleghem P. A., Calibrating Simple Models for Mixing and Flow Propagation in Waste Water Treatment Plants, Water Science and Technology, Vol. 39, Issue 4, pp 61-69 (1999).

Vayenas, D. V., Pavlou, S. and Lyberatos, G., Development of a Dynamic Model Describing Nitritification and Nitratification in Trickling Filters, Wat. Res., Vol. 31, Issue 5, pp 1135-1147 (1997).

Suman, D. S. and Anjaneyulu, Y., Evaluation of Biokinetic Parameters for Pharmaceutical Wastewaters Using Aerobic Oxidation Integrated With Chemical Treatment, Process Biochemistry, Vol. 40, Issue 1, pp 165-175 (2005).

Alaton, I. A., et al, Combined Chemical and Biological Oxidation of Penicillin Formulation Effluent, Journal of Environmental Management, Vol. 73, Issue 2, pp155-163 (2004).

Wheatley, A.D. and Williams, I.L., Pilot Scale Investigation Into the Use of Random Pack Plastics Filter Media in the Complete Treatment of Sewage, Water Pollution Control, Vol. 75, Issue 4, pp 468-486 (1976).

Pullen, K.G., Trials On the Operation of Biological Filters, Water Pollution Control, Vol.76, Issue 1, pp 75-85 (1976).

Gray, N.F. and Learner, M.A., A Pilot -Scale Percolating Filter for Use in Sewage Treatment Studies", Wat. Res., Vol. 17, No 3, pp 249-253 (1983).

Hemming, M.L. and Wheatley, A.D., Low-rate Biofiltration Systems Using Random Plastic Media, Water Pollution Control, Vol. 78, Issue 4, pp 45-68 (1978).

Christoulas, D.G. et al, Performance Relationship for Low and Intermediate Rate Biological Filters, Wat. Res., Vol. 24, No 5, pp 607-614 (1990).

Krumins, V. M. et al, Fluid Velocity Distribution in Nitrifying Trickling Filters: Mathematical Model and NMR Calibration, Wat. Res., Vol. 34, Issue 8, pp 2337-2345 (2000).

Hosono, Y., Kunora, H. and Miyaji, Y., Characteristic Evaluation of Trickling Filter Process, Wat. Res., Vol. 14, pp 581-590 (1978). 
Nenov, V., TSS/BOD Removal Efficiency and Cost Comparison of Chemical and Biological Wastewater Treatment, Water Science and Technology, Vol. 32, No 4, pp 207-214 (1995).

Nandy, T., et al, Optimization of Coagulants for Pretreatment of Printing Ink Wastewater, Environmental Engineering Science, Vol. 19, No 1, pp 1-7, (2002).

Howland, W. E., Flow over Porous Media as in a Trickling Filter, Proc. $12^{\text {th }}$ Ind. Waste Conf. Purdue Univ., pp 435-465 (1958).

Miao, J., et al, Restaurant Emission Removal by Biofilter with Immobilized Bacteria, Zhejiang Univ SCI 6B(5), pp 433-437(2004).

Koh, L.H, et al, Pre-Treatment of Volatile Organic Compounds Up-Stream of Biological Gas Cleaning Operation, Journal of Chemical
Technology and Biotechnology, Vol.79, pp 619625 (2004).

Lu, Z.J. et al, Biofiltration of Concentration Mixtures of Hydrogen Sulfide and Methanol, Environmental Progress, Vol. 22, No. 2, pp 129-136 (2003).

Neal, A.B., et al, Use of Biofilters and SuspendedGrowth reactors to Treat VOCs, Waste Management, Vol. 20, pp 59-68 (2000).

Wang, Z.H., et al, Study on the Effects of Cooking Oil Fume Condensate on the DNA Integrality", Journal of Hygiene Research, Vol. 31,No 4, pp 238-240 (2002).

Logan, B.E., et al, Molecular Size Distribution of Dissolved Organic Matter in Wastewater Transformed by Treatment in a Full-Scale Trickling Filter, Water Environmental Research, Vol.72, No.3, pp 277-281 (2000). 